\title{
Measuring Energy Security: \\ Trends in the Diversification of Oil and Natural \\ Gas Supplies
}

Gail Cohen, Frederick Joutz and Prakash Loungani 


\title{
IMF Working Paper
}

Research Department

\section{Measuring Energy Security:}

\section{Trends in the Diversification of Oil and Natural Gas Supplies}

Prepared by Gail Cohen, Frederick Joutz and Prakash Loungani*

\section{This Working Paper should not be reported as representing the views of the IMF.}

The views expressed in this Working Paper are those of the author(s) and do not necessarily represent those of the IMF or IMF policy. Working Papers describe research in progress by the author(s) and are published to elicit comments and to further debate.

February 2011

\begin{abstract}
We present evidence on one facet of energy security in OECD economies - the extent of diversification in sources of oil and natural gas supplies. Viewed from the perspective of the energy-importing countries as a whole, there has not been much change in diversification in oil supplies over the last decade, but diversification in sources of natural gas supplies has increased steadily. We document the cross-country heterogeneity in the extent of diversification. We also show how the extent of diversification changes if account is taken of the political risk attached to suppliers; the size of the importing country; and transportation risk.

JEL Classification Numbers: Q4; Q41; Q43; L71; E3; N5; N50

Keywords: Energy Security; Energy Independence; Diversification; OECD Energy Use Author e-mail: ploungani@,imf.org

\footnotetext{
* Author affiliations: Cohen: U.S. Congress; Joutz: George Washington University; Loungani: IMF. The views expressed in this paper are those of the authors and should not be attributed to the institutions with which they are affiliated. We received valuable comments from Andre Plourde, Stephen Brown and participants at the 2009 AEA meetings and the 2010 IAEE International conference. We are grateful to: Jair Rodriguez for yeoman's work in assembling the large data set and carrying out the computations; Hites Ahir, Warren Carnow and Marina Rousset for excellent research assistance at critical junctures; Chloe Le Coq, Elena Paltseva, Eshita Gupta and Lars-Hendrik Roller for making available their data sets to enable us to cross-check some of the computations; and Thomas Helbling and Nese Erbil for references to the literature.
} 
1. Introduction

2. Diversification in Sources of Energy Supply......................................................5

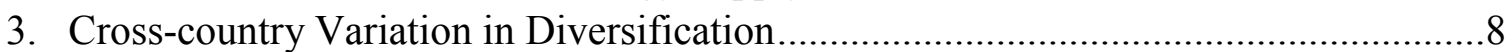

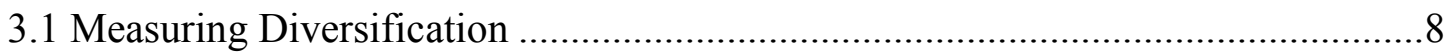

3.2 Adjusting for Political Risk and Country Size......................................................10

3.3 Diversification in Sources of Supply: Results .....................................................12

3.4 Combining the Oil and Gas Diversification Indices ............................................15

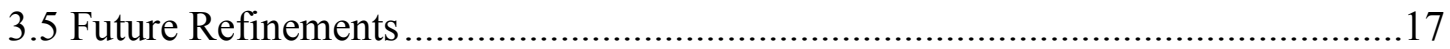

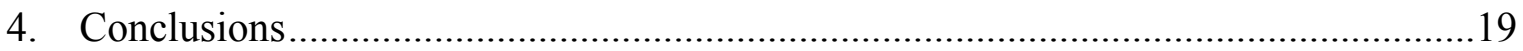

\section{Figures}

1. Normalized Global Consumption of Oil and Natural Gas ...................................22

2. Oil Production and Net Exports, by Major Countries.............................................23

3. Gas Production and Net Exports, by Major Countries............................................24

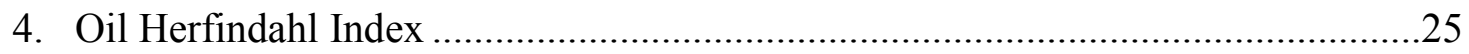

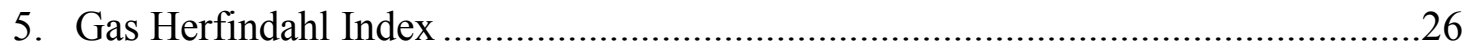

\section{Tables}

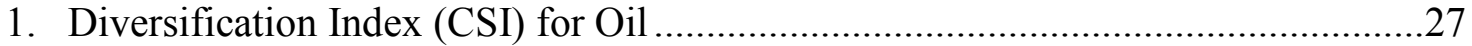

2. Diversification Index (CSI) for Oil, Adjusted for Political Risk ............................28

3. Diversification Index (CSI) for Oil, Adjusted for Country Size ……………...........29

4. Diversification Index (CSI) for Oil, Adjusted for Distance .....................................30

5. Diversification Index (CSI) for Oil, Adjusted for Political Risk,Size and Distance31

6. Diversification Index (CSI) for Natural Gas .........................................................

7. Diversification Index (CSI) for Natural Gas, Adjusted for Political Risk ................33

8. Diversification Index (CSI) for Natural Gas, Adjusted for Country Size ..................34

9. Diversification Index (CSI) for Natural Gas, Adjusted for Distance.........................35

10. Diversification Index (CSI) for Natural Gas, Adjusted for Political Risk, Size and

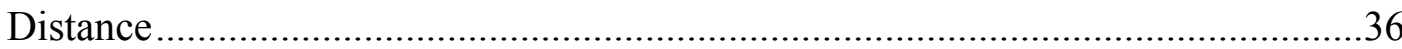

11. Energy Diversification Based on CSI Values in 2007-08....................................37

12. Share-weighted Diversification Indices (Based on 2008 Index for Oil and 2007

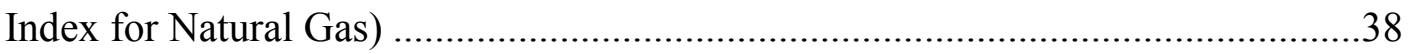




\section{Introduction}

The pursuit of energy security gained world-wide impetus after the tripling of the international price of crude oil in October 1973. One of the consequences of this shock was to put energy security and, more specifically, security of oil supply at the heart of the energy policy agenda of most industrialized nations" (LaCasse and Plourde, 1995). The run-up in oil prices over 2007-08 again raised the profile of energy security policies. Over 180 bills with the term -energy security" in the text of the bill were introduced into the U.S. Congress during the $111^{\text {th }}$ Congress (2009-10) and over 200 bills were introduced during the Congress that preceded it. In other countries around the globe as well, energy security is a key policy concern — see the special issue of Energy Policy on the topic (Loschel, Moslener, Rubbelke 2010a summarize the papers).

Policymakers often equate the attainment of energy security with _energy independence. ${ }^{2}$ Rising imports as a share of total consumption is thus taken to imply lower energy security, without an analysis of a country`s vulnerability to supply disruptions or energy price increases. Equating security with independence also leads policymakers to focus primarily on promoting expanding domestic supplies - for example through subsidies or quotas on domestic production - rather than on efficient methods to manage risk by diversifying suppliers or enhancing substitution among fuel types.

\footnotetext{
${ }^{2}$ There has been an explosion of popular books dealing with the elusive quest for energy independence, such as Bryce (2008), Hakes (2008) and Sandalow (2008)—see Loungani (2009) for a review of these books.
} 
A multi-faceted measure of energy security would help make better policy decisions, and also provide a way to track how policy decisions raise or lower energy security. Luckily, there is a growing literature on the measurement of energy security. Many papers seek to quantify the security of energy supplies for importing countries, using - in addition to the degree of import dependence-measures such as the extent of diversification in sources of supply and the distance between the source of the supplies and the point of consumption (Blyth and Lefevre 2004; Le Coq and Paltseva 2008, 2009; Gupta 2008). This paper contributes to this literature on the measurement of the short-run security of energy supplies. Our specific contributions are the following:

- $\quad$ First, we provide evidence of the variation over time from 1990 to the present in energy supply security for a broad set of countries, viz., the oil-importers among the OECD countries. ${ }^{3}$ Other studies have tended to provide evidence for a single year (e.g. Le Coq and Paltseva provide evidence for 2006 and Gupta for 2004).

- $\quad$ Second, while many previous studies have focused on oil, we also provide evidence on security for natural gas, another major energy source. This is important given the growing importance of natural gas in world energy consumption (see Figure 1). The globalization of energy markets is only likely to grow as natural gas grows in importance. Traditionally, natural gas has been traded in regional, intra-continental, markets. But as the costs of transporting natural gas have fallen, trade in natural gas

\footnotetext{
${ }^{3}$ In principle, one could also study the energy vulnerability of the major oil exporters. Bryce (2008) notes that in 2005 the -Saudis imported 83,000 barrels of gasoline and other refined oil products per day" and Iran imports 40 percent of its gasoline needs.
} 
has increased dramatically; the IEA estimates that international spot trade of gas has grown by a factor of 10 over the last decade (Rosendahl and Sagen, 2009).

\section{Diversification in sources of energy supply}

Casual empiricism suggests that diversification in sources of energy supply has been increasing. Bryce (2008) notes, for instance, that the United States buys crude oil and gasoline from over 40 countries and jet fuel from over 25 countries. Canada and Mexico have grown in importance as suppliers, whereas countries of the Persian Gulf supply now only about 10 percent of all the oil consumed in the United States.

Figures 2 and 3 show the present distribution of major producers and net exporters of oil and gas compared with that in 1992. The top panel of Figure 2 shows that the major change among producers of oil has been the decline in the share produced by the United States. Among net exporters (shown in the bottom panel), the major changes over time have been the decline in the shares of Saudi Arabia, Iran, UAE, Indonesia and Mexico and a corresponding increase in the shares of Russia and Angola. Among gas producers, the biggest changes, as shown in the top panel of Figure 3, have been the declines in the shares of Russia and the US. Among net exporters (bottom panel), the main developments have been the growing importance of Norway and the emergence of several new producers such as Qatar, Turkmenistan, the Netherlands, Nigeria, Egypt and Australia.

Diversification indices can provide a summary statistic of these changes over time. The basic idea of a diversification index is borrowed from portfolio theory in finance: holding other things constant, the overall risk to energy supplies is smaller if there is a 
diversified portfolio of suppliers. Diversification in sources of supply can reduce vulnerability to supply disruptions from a particular source. Moreover, even in the absence of supply disruptions, diversification reduces the market power of any one supplier, lowering the risks of higher prices and/or inferior products and services" (Blyth and Lefevre, 2004, p. $18)$.

This idea can be quantified in a number of different ways. Much of the literature (Blyth and Lefevre 2004; Le Coq and Paltseva 2008, 2009; Gupta 2008; Loschel, Moslener, Rubbelke 2010b) uses the Herfindahl-Hirschmann index to measure diversification. This index is equal to the sum of the squares of each supplier's market share. Thus the more concentrated the market, the higher is the value of the index; the maximum value of the index is achieved when there is only one supplier.

We construct two versions of the diversification index, one using each country's share of total production and the second using each country`s share of net exports.

$$
\text { CSI }(\text { global })=\sum_{i}\left(\frac{X_{i}}{X}\right)^{2} * 100
$$

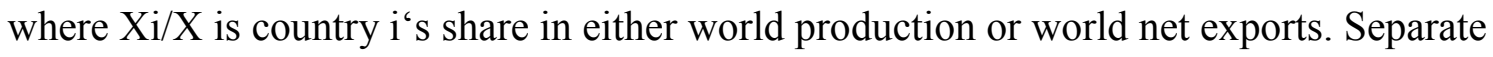
indices are constructed for oil and natural gas. These indices are shown in the top panels of Figure 4 and Figure 5, respectively for oil and natural gas.

The CSI (global) measure assumes that the risk of disruption is the same across energy suppliers. This of course need not be the case. While there is no easy way of 
quantifying risks associated with a particular supplier (or of measuring the correlation of risks among suppliers), a common practice in the literature is to proxy it by broader measure of country risks. The most widely used measure, and the one used in this paper, is a country's political risk rating as computed by the Political Risk Services group and reported in the International Country Risk Guide (ICRG). The political risk rating provides a means of assessing the political stability of the countries covered by $I C R G$ on a comparable basis.

$$
C S I_{p o l}(\text { global })=\sum_{i}\left[\left(\frac{X_{i}}{X}\right)^{2} * P O L_{i}\right]
$$

where $\mathrm{POL}_{\mathrm{i}}$ is computed as:

$$
P O L_{i}=\left[100-I C R G_{i} / 100\right]
$$

Since $\operatorname{ICRG}_{\mathrm{i}}$ is on a $(0,100)$ scale where high values indicate low political risk, the transformation above is made to ensure that $\operatorname{CSI}_{p o l}$ (global) moves in the same direction as CSI (global).

Figure 4 shows the diversification over time in the sources of oil production (left hand panels) and net exports (right hand panels). As shown, there was an increase in diversification in oil supplies and net exports between 1992 and around 2000, but it has essentially leveled off since then. The adjustment for political risk, shown in the bottom panels of Figure 4, does not make a big difference, suggesting that though there have been many changes in the sources of production and net exports over this time, the risk factors of the countries whose shares have increased has roughly balanced out the risk factors of those whose shares have fallen. 
Figure 5 shows that the picture for natural gas is quite different from that for oil. There has been a steady decline in the values of the index, indicating increased diversification in sources of production and net exports. Adjustment for political risk does not alter this trend.

To summarize, viewed from the world's perspective, there has not been significant change in diversification in oil supplies over the last decade but there has been a steady increase in diversification in natural gas supplies. Given the increasing importance of natural gas in world energy use, this points to an increase in overall energy security. Of course, the picture from the perspective of an individual energy-importing country could look quite different, depending on its relative use of oil and natural gas, its dependence on imports relative to domestic production, the particular countries from which it imports, and the political risk attached to the sources of those imports. The next section presents our countrylevel results on diversification. In addition to adjustments to political risk, we also adjust the diversification indices for the size of the importing country and the distance between the importing country and the source of its imports (as a proxy for transportation risks).

\section{Cross-country variation in diversification}

\subsection{Measuring diversification}

We again follow the literature in using diversification indices to measure the risk of disruption to an individual country's energy supplies. While the Le Coq \& Paltseva $(2008,2009)$ and Gupta (2008) papers use the actual market share of each supplier, Blyth and 
Lefevre (2004) argue that what matters are the potential exports of each supplier (the supplier`s production less its consumption). There are pros and cons of each approach. Le Coq and Paltseva (2009) argue that using potential exports - may not reflect the short-term threats in the actual energy market faced by the country in question." While they agree that the Blyth \& Lefevre approach -eould be better suited for reflecting the possibility of switching to a different supplier in the case of a disruption" they view their approach as preferable if the interest is in describing a country's ability to carry out — \$hort-run adjustment to shocks in which case a change in supplier is highly relevant."

Neuman $(2004,2007)$ uses a Shannon-Weiner concentration index, which is calculated by multiplying the market share for each participant by the log of the market share and summing up the absolute values of the products over all the suppliers. This index gives greater weight to the impact of the smaller participants, whereas HHI gives greater weight to the larger suppliers. The argument for the former index is that it is the smaller suppliers that are more likely to be able to provide options for switching between energy sources in the event of a disruption to another supply source. Le Coq and Paltseva argue that HHI, with it emphasis on the larger suppliers is better suited to capture the risks associated with the nondiversified energy portfolios" (2008b, p.7-8).

While each measure thus highlights a different facet of diversification, our work in this paper is based on the HHI as defined by Le Coq and Paltseva. Specifically, we compute a country-specific index for the concentration in suppliers as:

$$
C S I=\sum_{i}\left(\frac{N P I_{i}}{C}\right)^{2} * 100
$$


where $\mathrm{C}$ is country $\mathrm{j}^{\text {'s }}$ total consumption of the fuel. $\mathrm{NPI}_{i}$, the net positive imports from country $\mathrm{i}$ to country $\mathrm{j}$, are defined as:

$$
N P I_{i}=\max \left\{0, M_{i j}-X_{i j}\right\}
$$

$\mathrm{M}_{\mathrm{ij}}$ is imports of energy from country $\mathrm{i}$ to $\mathrm{j}$ and $\mathrm{X}_{\mathrm{ij}}$ is exports of energy from country $\mathrm{j}$ to $\mathrm{i}$. As noted earlier, smaller values of CSI indicate more diversification and hence lower risk; in the case of only one supplier, CSI takes on its maximum value of 100. It is important to note that, other things equal, CSI will be lower in countries where net imports form a smaller part of consumption. Hence CSI is likely to be correlated with the measures of import dependence" that are commonly used.

\subsection{Adjusting for political risk and country size}

The CSI measure assumes that the risk of disruption is the same across energy suppliers. This of course need not be the case. While there is no easy way of quantifying risks associated with a particular supplier (or of measuring the correlation of risks among suppliers), a common practice in the literature is to proxy it by broader measure of country risks. The most widely used measure, and the one used in this paper, is a country's political risk rating as computed by the Political Risk Services group and reported in the International Country Risk Guide (ICRG). The political risk rating provides a means of assessing the political stability of the countries covered by ICRG on a comparable basis.

$$
C S I_{p o l}=\sum_{i}\left[\left(\frac{N P I_{i}}{C}\right)^{2} * P O L_{i} * 100\right]
$$

where, as before, $\mathrm{POL}_{\mathrm{i}}$ is computed as:

$$
P O L_{i}=\left[100-I C R G_{i} / 100\right]
$$


Since $\mathrm{ICRG}_{\mathrm{i}}$ is on a scale where high values indicate low political risk, the transformation above is made to ensure that $C S I_{p o l}$ moves in the same direction as CSI. $C S I_{p o l}$ takes values in the range $(0,100)$.

Thus far, the indices do not take into account differences in country size, and therefore in the size of their consumption (or imports) relative to world consumption (or imports). Blyth and Lefevre suggest that this can be an important factor in determining the potential vulnerability of an importing country. Other things constant, the smaller is the importing country's draw on the market, the easier it is for the country to switch suppliers in the event of a disruption from one source. Constraints to switching suppliers raise the vulnerability to energy shocks and lower a country's energy security. We proxy this country size effect by constructing a variable, SIZE, which is the ratio of total world consumption of a fuel source divided by the consumption of the country, expressed in percent terms. ${ }^{4}$

$$
C S I_{\text {size }}=\sum_{i}\left[\left(\frac{N P I_{i}}{C}\right)^{2} \times e^{(1 / S I Z E)} * 100\right]
$$

Following Blyth and Lefevre, the size of a country's consumption and imports relative to world consumption has a multiplicative effect on a country`s energy security. Thus, SIZE is included in the overall index in an exponential function. Countries with a relatively small share of world consumption (i.e. 1/SIZE close to zero) will not have their risk assessment altered very much. Countries whose draw on available world supply is significant, and thus will have more difficulty in replacing supply in the event of a disruption, will have their security risk scaled up quite a bit.

\footnotetext{
${ }^{4}$ Using the ratio of world imports of a fuel source to the country's imports gave us similar results.
} 
The last adjustment, following Le Coq and Paltseva (2009), is to -enstruct a measure of the distance between the supplier and the consuming country as a proxy for the potential risks of energy transportation." They argue that the -safety of delivery to the consuming country declines with the distance to the energy source." In practice, they use the distance between the capitals of the consuming and supplying countries to construct an adjusted CSI:

$$
C S I_{d i s t}=\sum_{i}\left[\left(\frac{N P I_{i}}{C}\right)^{2} * D_{i} * 100\right.
$$

where $\mathrm{Di}=1$ if the distance between the capital of the importing country and the supplying country is less than $1500 \mathrm{~km}$; $\mathrm{Di}=2$ if the distance is between 1500 and $4000 \mathrm{~km}$; and $\mathrm{Di}=3$ if the distance exceeds $4000 \mathrm{~km}$. Given the scaling of the Di variable, $C S I_{\text {dist }}$ takes on values in the range $(0,300)$.

We also construct an index which takes into account all three adjustments we have discussed, for political risk, size and distance.

\subsection{Diversification in sources of supply: Results}

The results are presented in Tables 1 to 10; the first five are for oil and the next five for natural gas. In each table results are presented for the years 1990, 1995, 2000 and the most recent year available, which is 2008 in the case of oil and 2007 in the case of gas. The number of countries is 26 for oil and 21 for gas $^{5}$. The main sources of the data are Eurostat

\footnotetext{
${ }^{5}$ The missing countries are Australia, Canada, Korea, New Zealand, and Turkey.
} 
for the European members of the OECD and the International Energy Agency (IEA) for the other countries.

Table 1 contains basic CSI indices. Looking first at the variation over time, it is the case that, for most countries, the value of the index has increased over time, that is, in the direction of lower security. This reflects the fact that, for most countries, imports have become a more important part of their overall consumption. Recall that the way our index is computed, this translates into a higher value for the index. A second noteworthy feature of Table 1 is the large cross-country variation in values of the index. In 2008, for instance, this variation spanned the range of CSI values from essentially zero in the case of the UK to 100 in the case of the Slovak Republic.

Table 2 shows that the adjustment for political risk makes a huge difference to the CSI indices. In 2008, the adjustment lowers CSI values for all but one country, reflecting the widespread move towards imports from countries such as Norway and Mexico, which have lower political risk ratings than many countries in the Middle East. The mean value for $\operatorname{CSI}_{p o l}$ is 6 compared with 27 for CSI; the standard deviation of $\operatorname{CSI}_{p o l}$ is about 7, compared with 28 for CSI. The adjustment for political risk of the oil suppliers thus significantly lowers the overall perception of the degree in energy vulnerability as well as cross-country differences in vulnerability.

In contrast to adjustment for political risk, the effect of the adjustment for size turns out to be anti-climactic. Table 3 shows the values for $C S I_{\text {size }}$. It is evident from comparing 
Tables 1 and 3 that the size correction only has a large impact on the values for the United States; the impact on other countries is minimal. Hence, the size correction significantly raises U.S. vulnerability.

Table 4 presents the results taking into account distance from suppliers. Comparing these numbers with those in Table 1, the main impact is that the values for countries in the Asia-Pacific region (Japan, Korea, Australia, New Zealand) increase substantially. Many European countries, such as Hungary, Slovak Republic and Switzerland also have higher CSI values with this adjustment.

Table 5 presents our overall assessment of oil vulnerability based on diversification in the sources of supply. It reports the values of the CSI index adjusted for political risk of the suppliers, size of the importing country, and distance between the importing country and its suppliers. For about two-thirds of the countries, there has been a decrease in CSI values - an increase in measured energy security - between 2000 and 2008. However, the reasons behind this development are multi-faceted. For quite a few countries, the decrease comes about not so much because of mere diversification in the sources of energy supplies but because of the lower political risk associated with some of their suppliers. There is also a lot of heterogeneity across countries for the reasons noted when discussing the individual adjustments - as noted, size distinguishes the U.S. from other countries because of the draw it would need to make on resources in the event of a supply disruption; distance matters for countries in the Asia-Pacific region because they are further away from the centers of 
production; and dependence on a few suppliers is a distinguishing feature of many of the smaller European countries.

Tables 6 to 10 present the CSI indices for natural gas. Since these tables are organized similarly to the ones just presented for oil, our discussion can be brief. Note that there are five fewer countries in these tables than in the oil tables. Three of the missing countries, Canada, New Zealand and Australia, are net exporters of natural gas. The other two countries, Korea and Turkey are excluded because of missing data. The main features of these tables are as follows. First, as with oil, the cross-country variation is much more significant than the changes for a particular country over time. For a few countries, Japan in particular, the time series variation is quite significant as well. Second, comparing Tables 6 and 7 , the adjustment for political risk again makes a big difference. Looking at the values for 2007 , for instance, the mean value of the index plummets from 42 to 9 after the adjustment, and the standard deviation falls from 33 to 7 . Third, comparing Tables 6 and 8 , the size adjustment barely makes a difference, even for the United States. Fourth, comparing Tables 6 and 9, the adjustment for distance raises CSI values quite significantly for Japan and a number of European countries such as Austria and Hungary.

Table 10 reports the values of the CSI index for natural gas, adjusted for political risk, country size and distance. With only a couple of exceptions (Japan prominent among them), there has been a decline in the CSI values -- an increase in measured energy security -- for all countries between 2000 and 2008. This reflects more diversification in sources of supplies but, more importantly, the lower political risk associated with these suppliers. 


\subsection{Combining the oil and gas diversification indices}

We characterize the present vulnerability of countries jointly based on the extent of their diversification in the sources of petroleum and natural gas in Table 11. Since Australia, Canada and New Zealand are net exporters of natural gas, they are not included in Table 11. The two countries with missing data, Korea and Turkey, are also not included in Table 11. Vulnerability is broken up into three categories based on the CSI values: _lbw' is less than 4, medium' ranges from 3 to 10 , and high' is greater than 10 . In the rows, we sort countries by petroleum vulnerability and they are sorted by the CSI for natural gas in the columns. Two countries, Denmark and the UK, appear to have a low vulnerability in terms of diversification for both fuels. At the other end of the spectrum the Czech Republic, Finland, Greece, Hungary, Japan and the Slovak Republic are highly vulnerable to supply shocks since they are not well diversified for either fuel. Only Ireland is found to have low vulnerability for one fuel (oil) and high vulnerability for the other fuel (natural gas). Four countries, Austria, Germany, Portugal, and Sweden, are highly vulnerable in terms of natural gas and are classified as having medium vulnerability in petroleum. Three countries, France, the Netherlands and the US, have medium vulnerability in terms of oil but low vulnerability in terms of natural gas.

Thus far, we have discussed the results for oil and gas diversification separately. To conclude the discussion of our results, we compute the weighted sum of the latest CSI values for oil and gas (i.e. the 2008 CSI for oil and the 2007 CSI for gas). In each case, the CSI adjusted for both political risk and size is used. Each CSI is weighted by the share of that 
energy source in the overall energy consumption of the country; the assumption is the risks from a lack of diversification in the supply of a particular energy source are greater, the more important that source is in the country's consumption basket. The results are shown in Table 12. The first column shows the values of the CSI index when the weights of oil and gas are normalized to sum to 1 . The second shows the CSI index without the normalization, i.e. the weights used are the ones shown in the third and fourth columns of the table. As suggested by the results for the individual fuel sources, when normalized weights are used, the countries which stand out as least and most vulnerable are essentially the same as before. Denmark and the U.K have the lowest values of the weighted CSI, while Poland, Finland and the Slovak Republic have the highest values. When the weights are not normalized to 1 , then there are some interesting shifts in the rankings. Countries such as Poland and Germany, where coal is an important part of energy consumption, now appear much less vulnerablethe change is most dramatic in the case of Poland.

\subsection{Future refinements}

Role of energy sources other than oil and natural gas: The CSI could be extended to incorporate sources other than the two we have focused on thus far. As noted, coal is an important energy source for some countries, and Table 12 already provides some evidence

of its importance. Since the extent of reliance on domestic supplies vs. imports for these omitted energy sources can be quite different from that for oil and natural gas, it would be 
important to incorporate them in future work to present a more robust picture of energy vulnerability. ${ }^{6}$

Interfuel substitution: CSI measures the diversification in supplies for each energy type separately. The implicit assumption is that there is no interfuel substitution, which Le Coq and Paltseva argue may be a reasonable one to make for the very short run. ${ }^{7}$ However, beyond the very short run, countries will have some ability to substitute one fuel for another, though the extent to which they can do so would differ across countries based on factors such as the sectoral breakdown of energy use (e.g. if the transportation sector looms large in energy use, the possibility of substitution might be low). Conceptually, one can accommodate interfuel substitution within the framework laid out in section 2-the weights assigned to the CSI for individual energy sources in constructing an index of overall vulnerability can be lower, the higher is the extent to which other energy sources can substitute for it. Serletis, Timilsina and Vasetsky (2009) provide evidence on cross-country interfuel substitution for a few of the countries in our sample; in ongoing work we are studying how the overall CSI for these countries changes if one takes into account the elasticities of substitution estimated by these authors. ${ }^{8}$

\footnotetext{
${ }^{6}$ Along with natural gas, the Canadian oil sands have also become an important part of the global energy picture. According to Yergin (2009), Canada's estimated recoverable reserve of petroleum is second only to Saudi Arabia's. Canada is the largest foreign supplier of oil to the U.S. market and its placid political environment could make it a reliable source of future energy supply.

${ }^{7}$ They state that -our index is designed to measure the short-term risk to the security of energy supply. We consider the case of a sudden disruption in supply that cannot immediately be accommodated by the market due to a lack of flexibility. For this type of disruption the substitutability among energy types is very limited (2008b, p. 3)."

${ }^{8}$ While evidence suggests that there is little interfuel substitution between oil and natural gas, there is stronger evidence of some substitutability between electricity and oil. In the United States, 23 percent of electricity is
} 
Current production vs. reserves: The CSI relies on data on the current production of the major oil and natural gas suppliers to the importing countries. However, for a forwardlooking assessment of energy vulnerability, what matters is whether the producer can continue to provide energy supplies in the future. An importing country may have a low CSI at present, but could be highly vulnerable in future if its major suppliers are running out of energy reserves. This suggests using data on years of crude oil and gas reserves remaining at current production levels to indicate the extent to which a country`s current CSI is a reliable indicator of future vulnerability. However, this is a more a physical measure than an economic one and is subject to technological change.

\section{Conclusions}

This paper has presented evidence on the measurement and attainment of energy security in OECD economies, with a focus on two major energy sources - oil and natural gas. Following the literature, we take diversification in sources of supply to be an important aspect of this security. Our main results are as follows:

- Viewed from the perspective of the energy-importing countries as a whole, diversification in oil supplies has remained constant over the last decade while diversification in natural gas supplies has steadily increased. Given the increasing importance of natural gas in world energy use, this points to an increase in overall energy security.

currently produced from natural gas, although the ability to expand production may be limited by the current stock of generating plants. 
- While there is great heterogeneity at the individual country level, diversification in sources of oil supplies has not increased for most countries since 1990 (Table 1), in contrast to the increase in diversification of natural gas supplies (Table 6).

- An adjustment for the political risk associated with each supplier shows that countries' diversification has indeed increased over time (Tables 2 and 6), consistent with the popular perception. The large impact of this adjustment points to the importance of using alternate measures of risk; it would also be important to look at whether an energy exporter's political risk rating is informative about the risk that it will be the source of an energy supply disruption.

- $\quad$ An adjustment for the country size of the importing coutnry (following Blyth and Lefevre) lowered measured energy security for the United States but did not impact other countries very much (Tables 3 and 7). An adjustment for the distance between energy-consuming and energy-producing countries, intended as a proxy for transportation risk, lowered energy security for countries in the Asia and Pacific regions (Tables 4 and 8 ) .

- An overall diversification index for oil and natural gas combined, using consumption shares of the two fuels as weights, has low values for the U.S. and the U.K (Table 12), suggesting greater energy security compared with other countries such as Japan. Within continental Europe there is much heterogeneity, with larger countries such as France and Germany having lower values of the index than smaller countries such as Finland and the Slovak Republic. 
In future work, we plan to refine the diversification indices in numerous ways. These include taking into account energy sources other than oil and natural gas; accounting for interfuel substitution; accounting for each supplier's reserves rather than just the supplier's current production; and including vulnerability measures for infrastructure like import facilities, pipelines, and transmission lines, and refinery capability for petroleum products.

Many authors, such as LaCasse and Plourde, have provided a broader discussion of the importance of the diversification of energy supplies relative to other factors in the attainment of energy security. The most prominent of these other factors are demand-side developments, either through increasing efficiency of energy use or conservation policies. LaCasse and Plourde argue that that reductions in the extent to which oil is used an input might be as important to energy security as changes in the composition of energy demand (i.e. away from imports towards domestic energy sources) or the security of physical supplies of energy. They also argue convincingly that energy security depends on the likelihood of energy price shocks or energy supply disruptions and on the macroeconomic impacts of these shocks. The macroeconomic impact depends partly on factors such as energy efficiency but can also depend on factors such as the central bank response to energy shocks and on labor market rigidities which can govern the response of the economy to shocks (energy shocks as well as others). This requires stepping outside the narrow framework of the computation of diversification indices and looking more broadly at (1) the likelihood of energy price shocks; (2) the evolving macroeconomic response to energy shocks; and (3) trends in energy efficiency. We plan to do this in future work. 
Figure 1

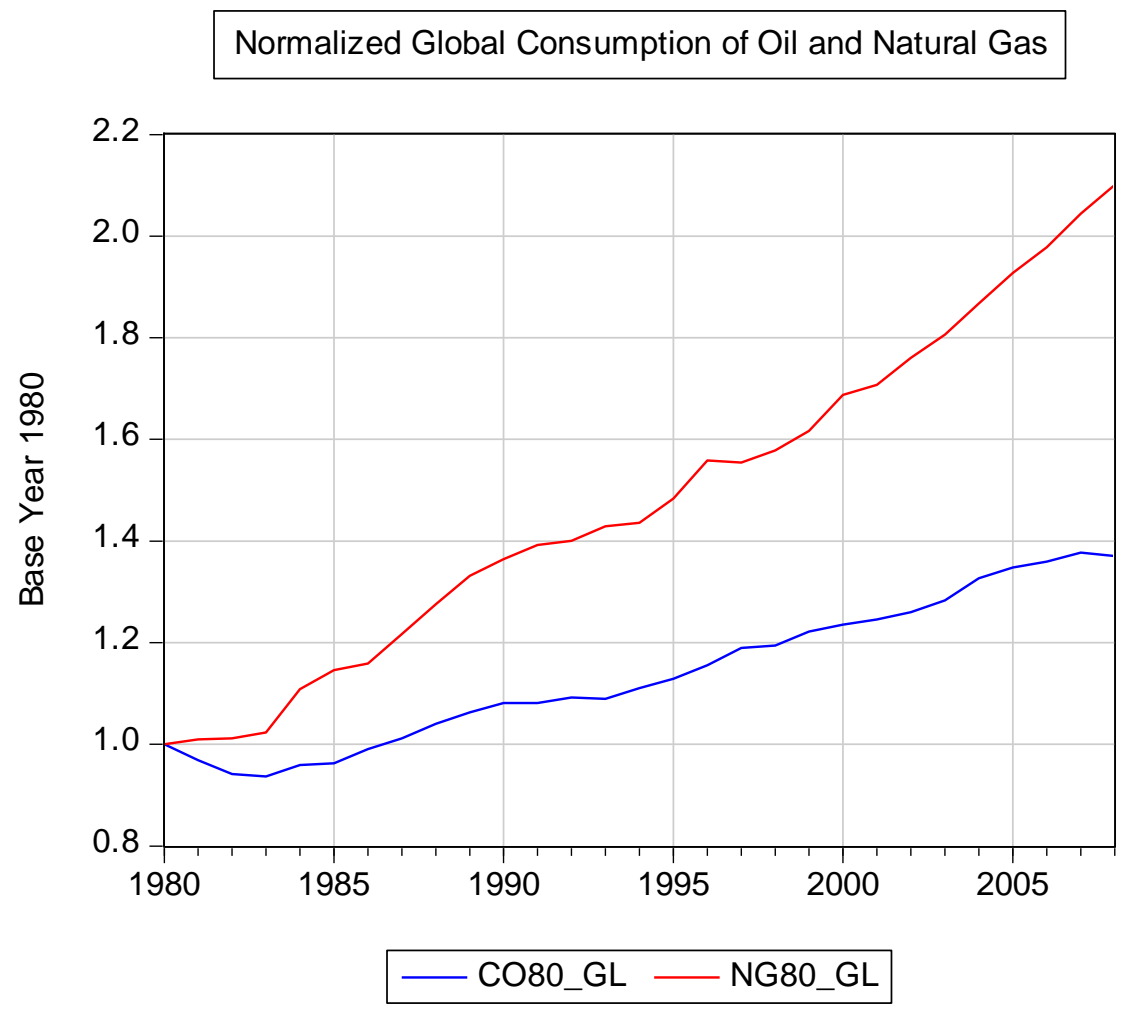


Figure 2. Oil Production and Net Exports, by Major Countries

Share of Oil Production in

Total World Production, 1992

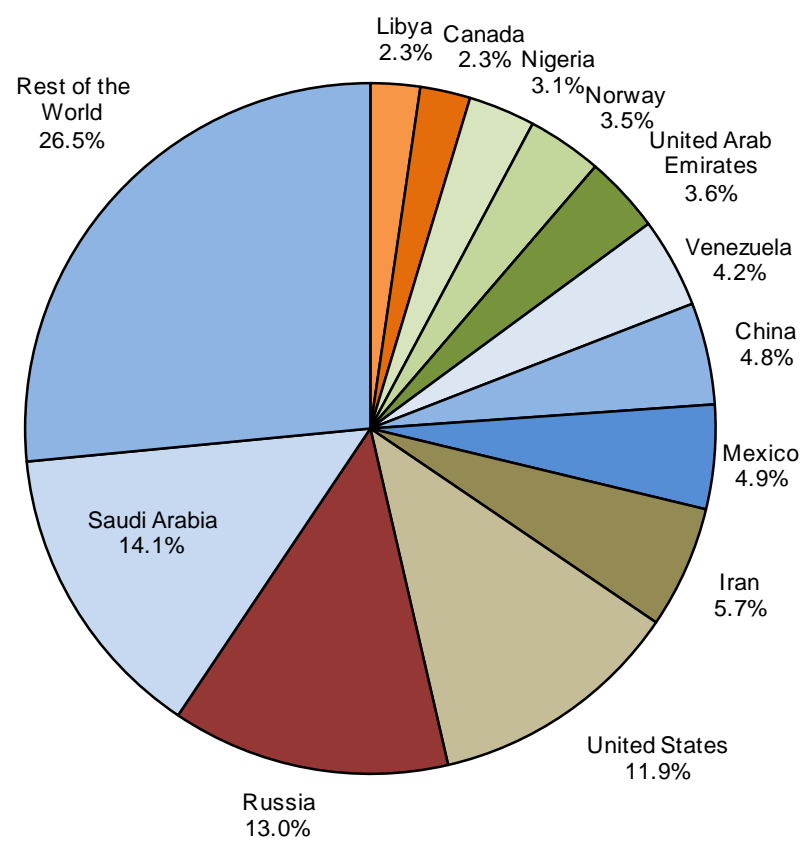

Share of Net Exporters in

Total Net Exports of Oil, 1992

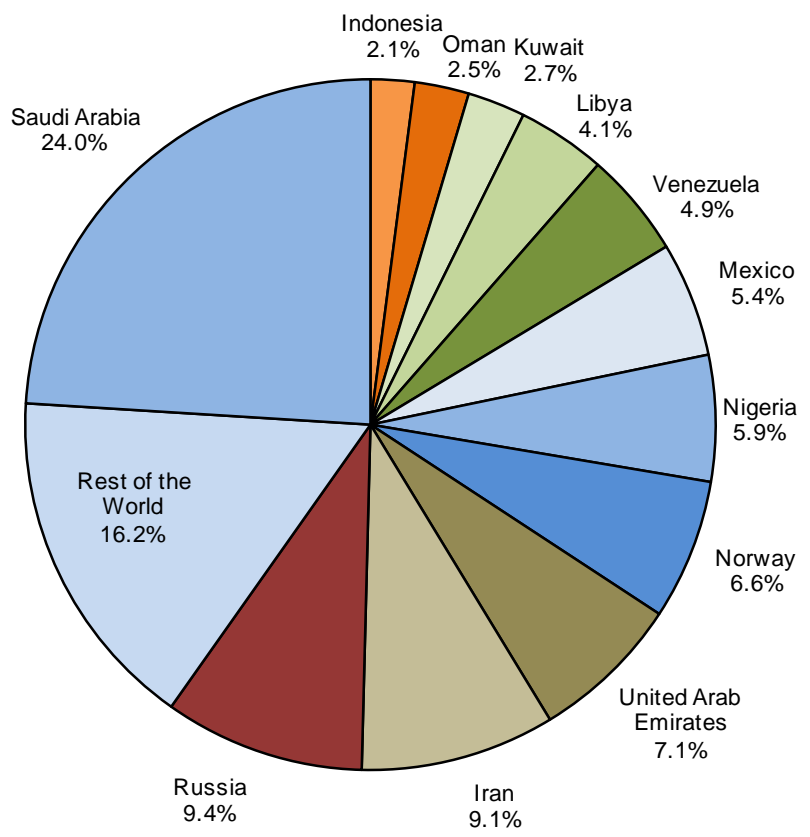

Share of Oil Production in

Total World Production, 2009

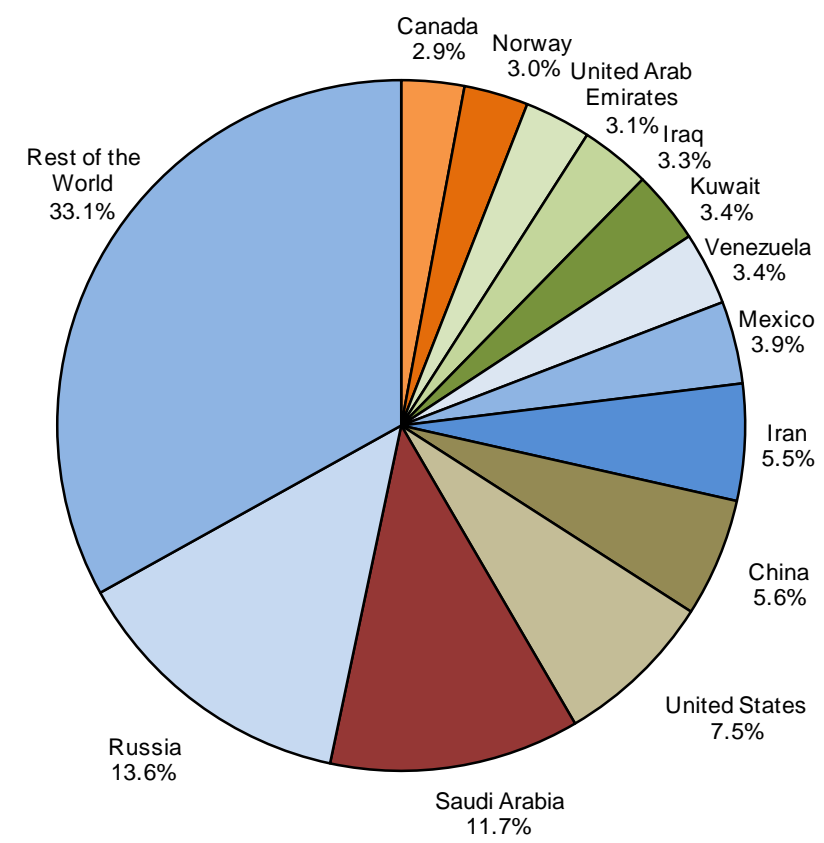

Share of Net Exporters in

Total Net Exports of Oil , 2008

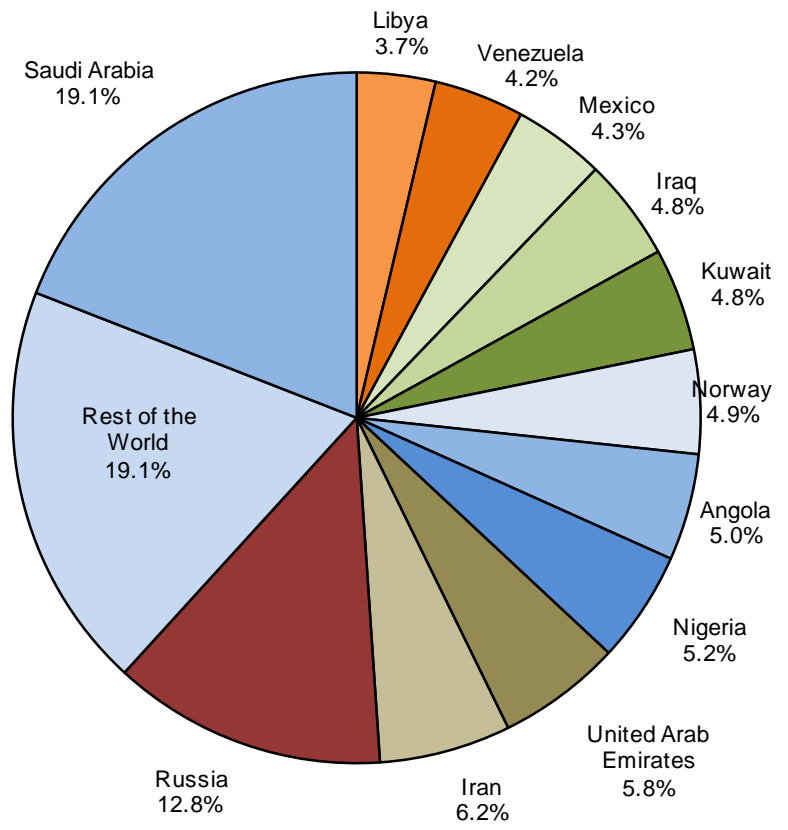


Figure 3. Gas Production and Net Exports, by Major Countries

Share of Gas Production in

Total World Production, 1992

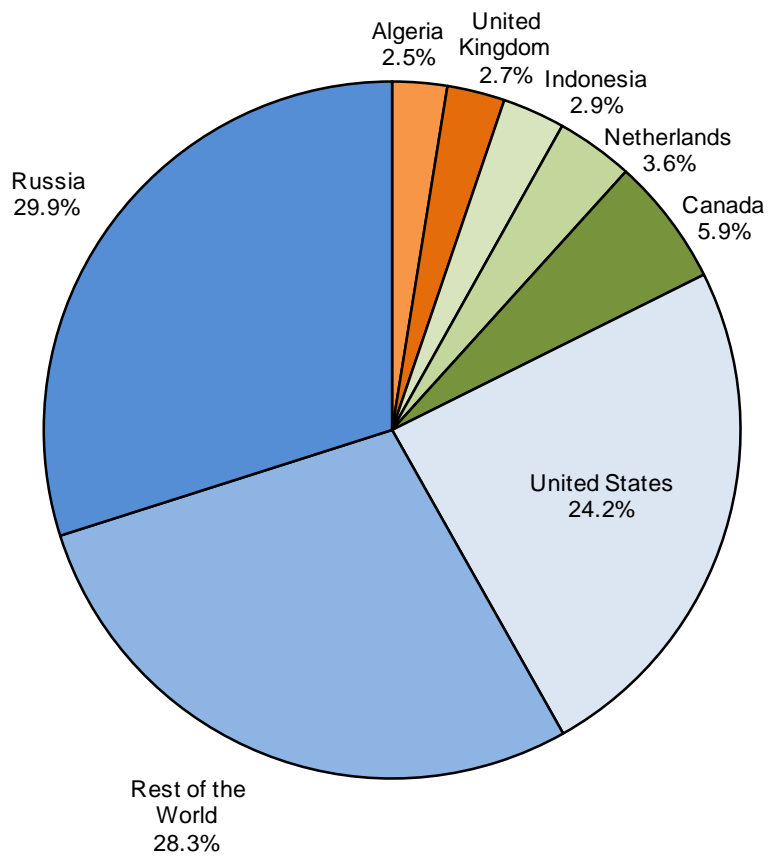

Share of Net Exporters in

Total Net Exports of Gas, 1992

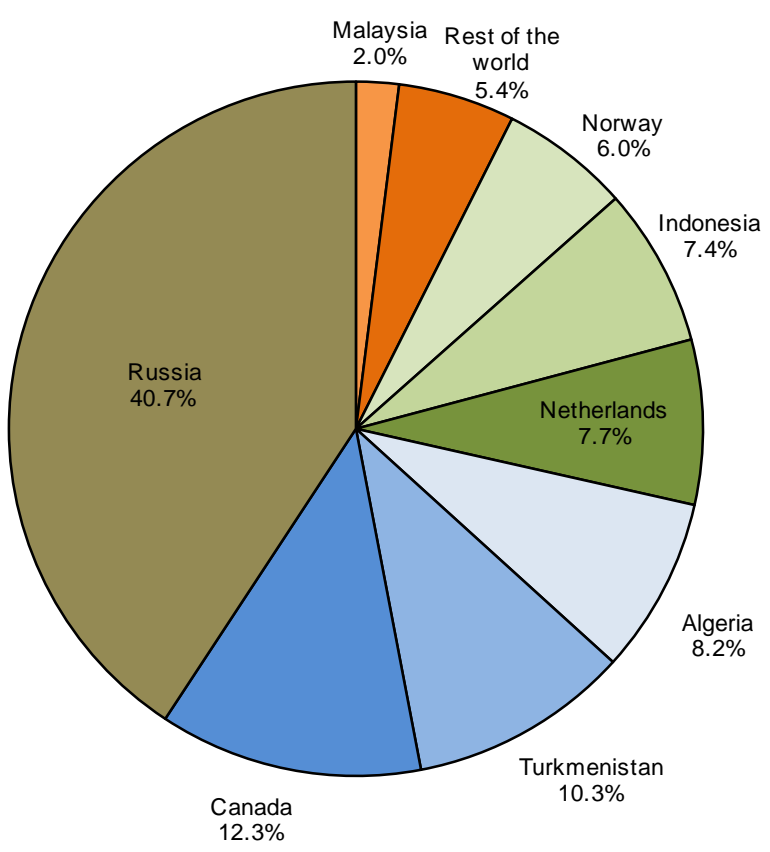

Share of Gas Production in

Total World Production, 2009

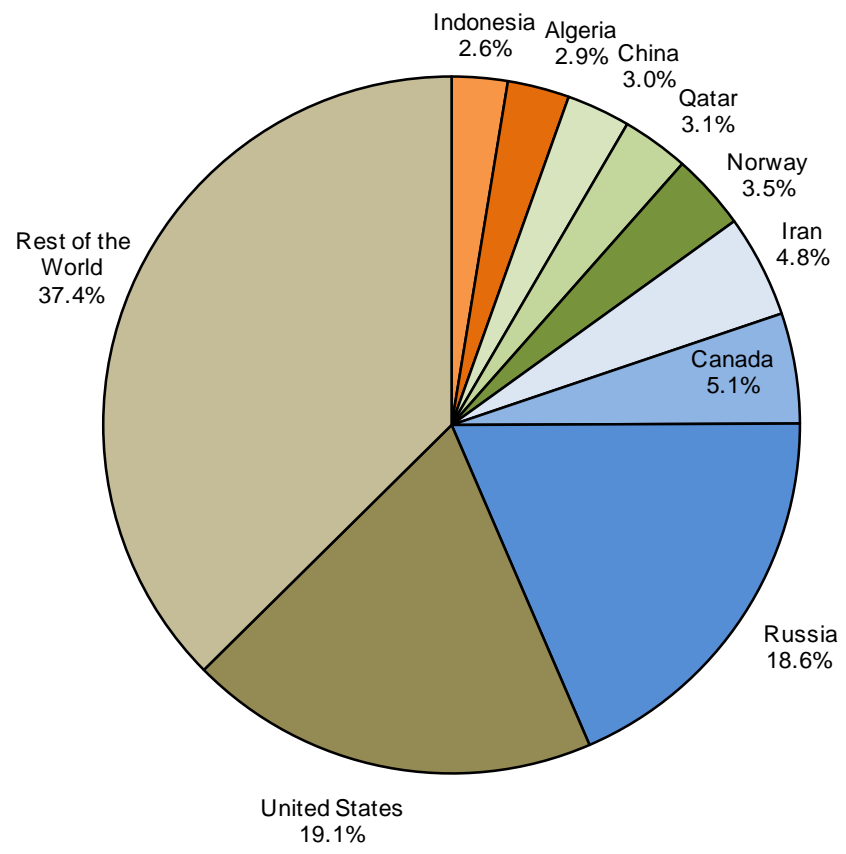

Share of Net Exporters in

Total Net Exports of Gas, 2008

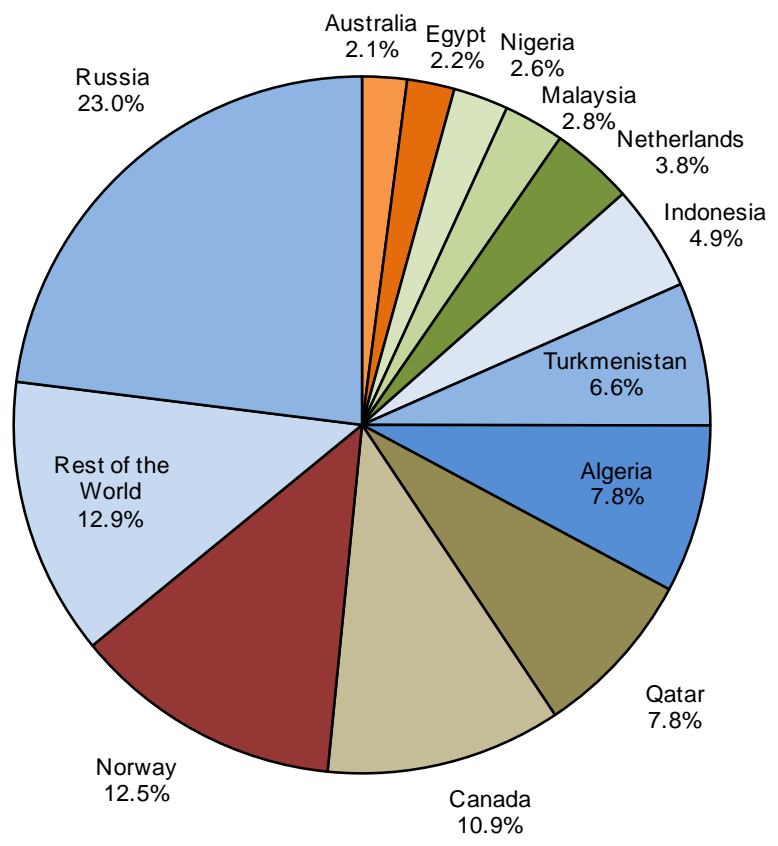


Figure 4. Oil Herfindahl index
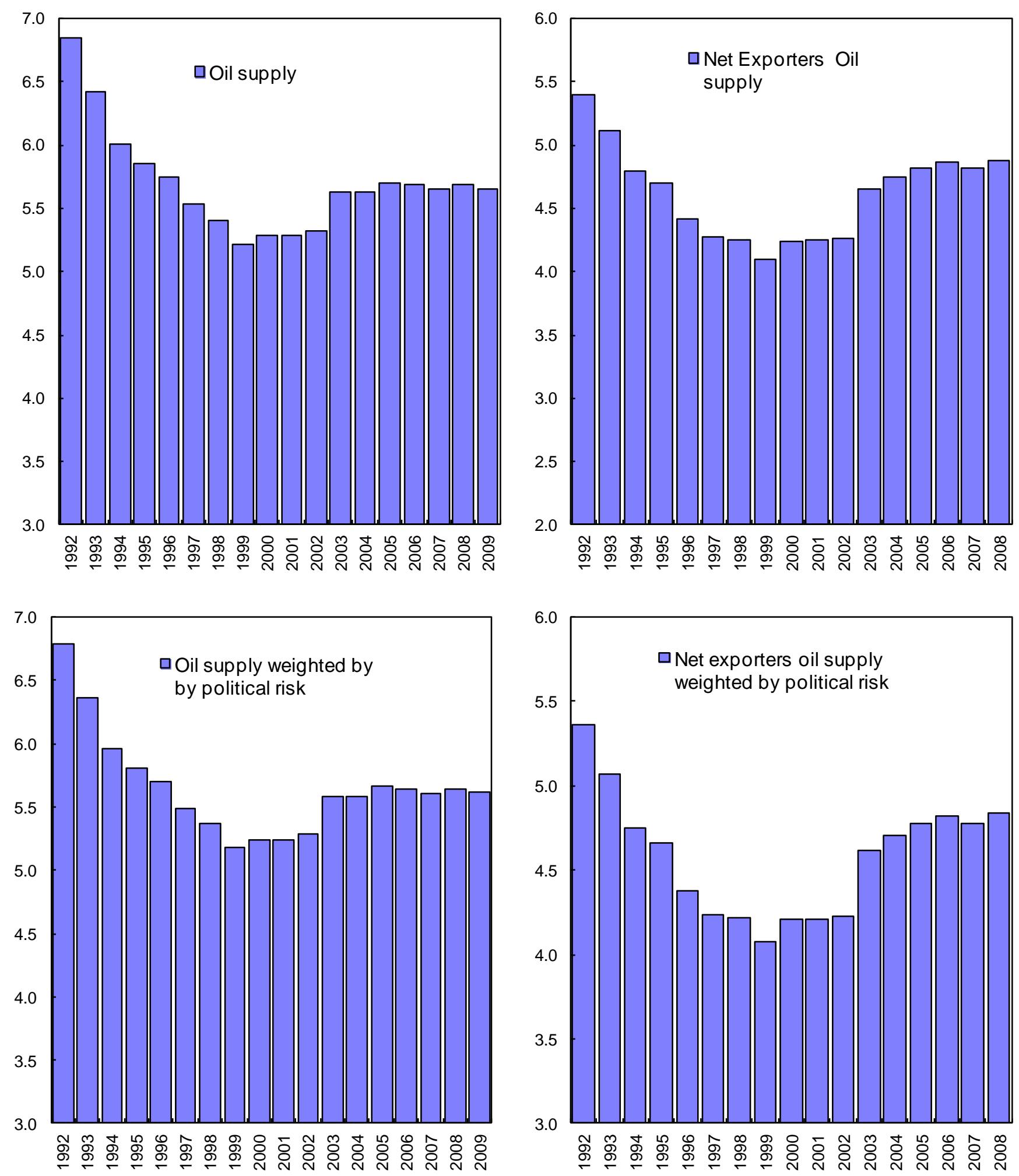
Figure 5. Gas Herfindahl index
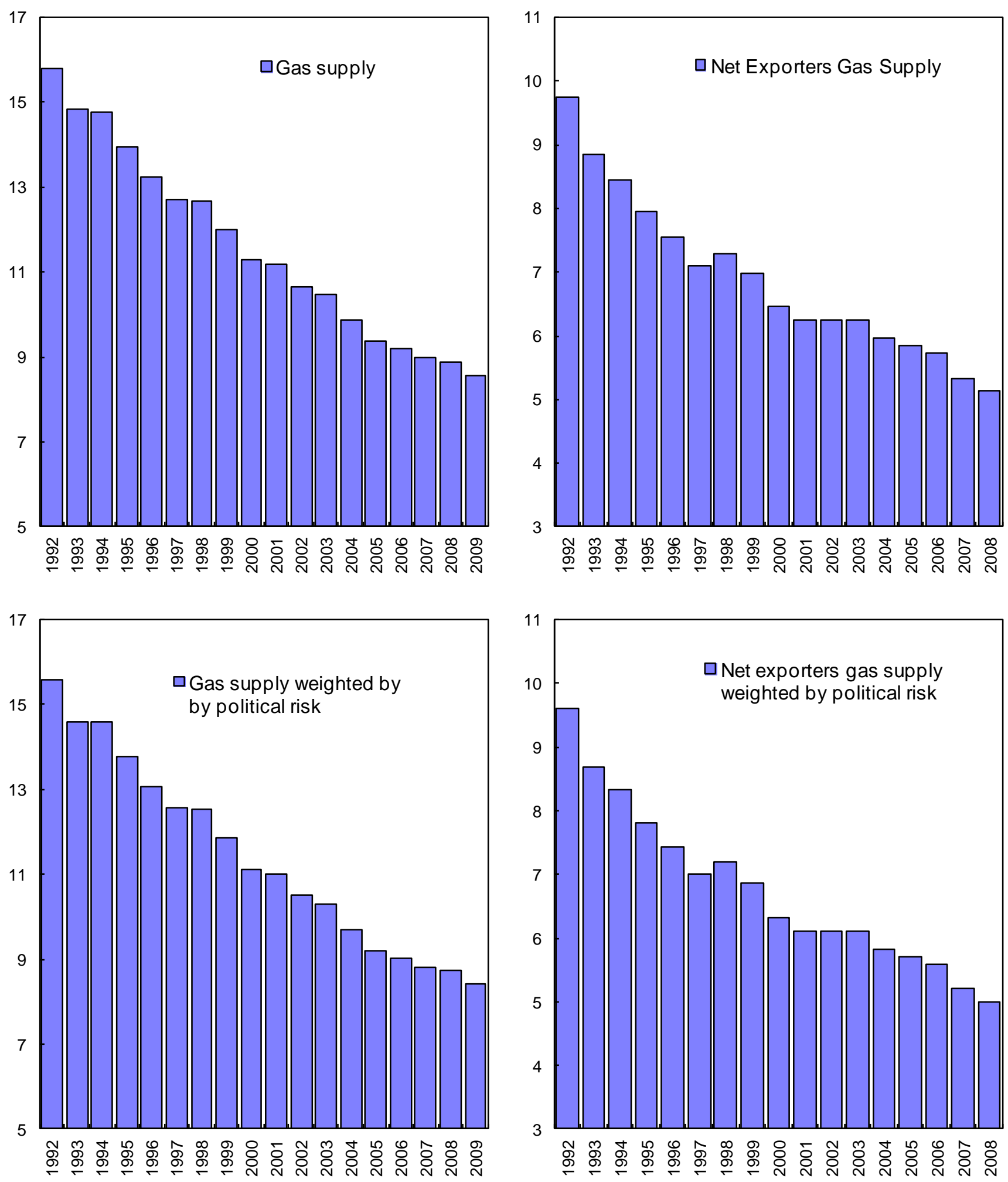
Table 1

Diversification index (CSI) for oil

\begin{tabular}{lrrrr}
\multicolumn{1}{c}{ Country } & & & & \\
\cline { 2 - 5 } & 1990 & 1995 & 2000 & 2008 \\
\hline Australia & 0.47 & 1.20 & 3.80 & 5.43 \\
Austria & 5.58 & 9.52 & 10.95 & 11.75 \\
Belgium & 15.54 & 23.18 & 17.64 & 21.60 \\
Canada & 1.13 & 2.15 & 7.80 & 5.42 \\
Czech Republic & & & 68.43 & 47.58 \\
Denmark & 4.93 & 13.01 & 12.45 & 8.56 \\
Finland & 4.28 & 22.61 & 29.70 & 73.37 \\
France & 7.44 & 13.22 & 12.45 & 8.47 \\
Germany & 6.11 & 13.41 & 15.67 & 15.31 \\
Greece & 28.12 & 26.13 & 24.74 & 27.33 \\
Hungary & & & 65.96 & 90.89 \\
Ireland & 64.30 & 74.06 & 100.00 & 33.53 \\
Italy & 13.40 & 15.88 & 12.76 & 13.83 \\
Japan & 10.88 & 13.82 & 16.33 & 17.46 \\
Korea & & 17.06 & 13.40 & 17.44 \\
Netherlands & 8.56 & 15.78 & 14.84 & 14.33 \\
New Zealand & 15.34 & 11.04 & 8.56 & 10.08 \\
Poland & & & 82.39 & 82.29 \\
Portugal & 12.45 & 16.16 & 15.48 & 10.57 \\
Slovak Republic & & & & 99.82 \\
Spain & 11.42 & 10.63 & 9.67 & 8.83 \\
Sweden & 23.18 & 29.56 & 26.11 & 22.81 \\
Switzerland & 26.20 & 30.93 & 32.17 & 53.75 \\
Turkey & 13.52 & 17.69 & 11.56 & 21.59 \\
United Kingdom & 2.35 & 2.13 & 14.16 & 15.70 \\
United States & 2.14 & 3.23 & 4.30 & 4.89 \\
\hline & & & &
\end{tabular}


Table 2

Diversification Index (CSI) for Oil, Adjusted for Political Risk

\begin{tabular}{lrrrr}
\multicolumn{1}{c}{ Country } & & & & \\
\cline { 2 - 5 } & 1990 & 1995 & 2000 & 2008 \\
\hline Australia & 0.17 & 0.34 & 1.41 & 1.41 \\
Austria & 2.91 & 3.73 & 4.64 & 3.64 \\
Belgium & 6.96 & 5.06 & 3.72 & 4.92 \\
Canada & 0.26 & 0.42 & 1.29 & 1.12 \\
Czech Republic & & & 27.64 & 11.43 \\
Denmark & 1.72 & 2.33 & 1.42 & 0.76 \\
Finland & 0.71 & 3.78 & 9.00 & 17.27 \\
France & 3.00 & 3.27 & 2.64 & 1.74 \\
Germany & 1.99 & 3.54 & 4.82 & 3.25 \\
Greece & 15.98 & 8.32 & 8.29 & 6.83 \\
Hungary & & & 26.66 & 21.53 \\
Ireland & 11.45 & 9.95 & 11.40 & 3.69 \\
Italy & 7.01 & 5.30 & 4.46 & 3.14 \\
Japan & 4.62 & 3.67 & 4.09 & 3.40 \\
Korea & & 4.56 & 3.55 & 3.39 \\
Netherlands & 3.97 & 3.50 & 3.11 & 3.23 \\
New Zealand & 5.90 & 2.88 & 2.07 & 1.98 \\
Poland & & & 33.29 & 19.45 \\
Portugal & 6.04 & 5.89 & 5.73 & 3.04 \\
Slovak Republic & & & & 23.65 \\
Spain & 5.02 & 3.73 & 3.57 & 2.20 \\
Sweden & 3.64 & 4.42 & 3.41 & 4.39 \\
Switzerland & 9.63 & 11.51 & 12.23 & 10.15 \\
Turkey & 8.34 & 5.21 & 4.31 & 5.83 \\
United Kingdom & 0.40 & 0.29 & 1.65 & 1.55 \\
United States & 0.82 & 0.96 & 1.27 & 1.17 \\
\hline & & & &
\end{tabular}


Table 3

Diversification Index (CSI) for Oil, Adjusted for Country Size

\begin{tabular}{|c|c|c|c|c|}
\hline \multirow[b]{2}{*}{ Country } & \\
\hline & 1990 & 1995 & 2000 & 2008 \\
\hline Australia & 0.49 & 1.23 & 3.90 & 5.55 \\
\hline Austria & 5.62 & 9.58 & 11.02 & 11.82 \\
\hline Belgium & 15.94 & 23.66 & 18.05 & 22.10 \\
\hline Canada & 1.21 & 2.25 & 8.19 & 5.65 \\
\hline Czech Republic & & & 68.70 & 47.85 \\
\hline Denmark & 4.96 & 13.11 & 12.52 & 8.61 \\
\hline Finland & 4.32 & 22.73 & 29.92 & 73.92 \\
\hline France & 8.01 & 14.06 & 13.21 & 8.96 \\
\hline Germany & 6.71 & 14.53 & 16.82 & 16.47 \\
\hline Greece & 28.52 & 26.44 & 25.07 & 27.67 \\
\hline Hungary & & & 66.28 & 91.32 \\
\hline Ireland & 64.43 & 74.19 & 100.20 & 33.61 \\
\hline Italy & 14.51 & 16.87 & 13.55 & 14.66 \\
\hline Japan & 13.20 & 16.46 & 18.92 & 19.81 \\
\hline Korea & & 18.23 & 14.57 & 18.86 \\
\hline Netherlands & 9.00 & 16.50 & 15.42 & 14.82 \\
\hline New Zealand & 15.41 & 11.07 & 8.59 & 10.11 \\
\hline Poland & & & 83.44 & 83.48 \\
\hline Portugal & 12.59 & 16.32 & 15.60 & 10.65 \\
\hline Slovak Republic & & & & 100.21 \\
\hline Spain & 12.04 & 11.10 & 10.06 & 9.18 \\
\hline Sweden & 23.58 & 29.98 & 26.48 & 23.13 \\
\hline Switzerland & 26.28 & 31.04 & 32.27 & 53.93 \\
\hline Turkey & 13.85 & 18.08 & 11.75 & 21.94 \\
\hline United Kingdom & 2.54 & 2.28 & 15.02 & 16.57 \\
\hline United States & 4.28 & 5.62 & 7.29 & 8.19 \\
\hline
\end{tabular}


Table 4

Diversification Index (CSI) for Oil, Adjusted for Distance

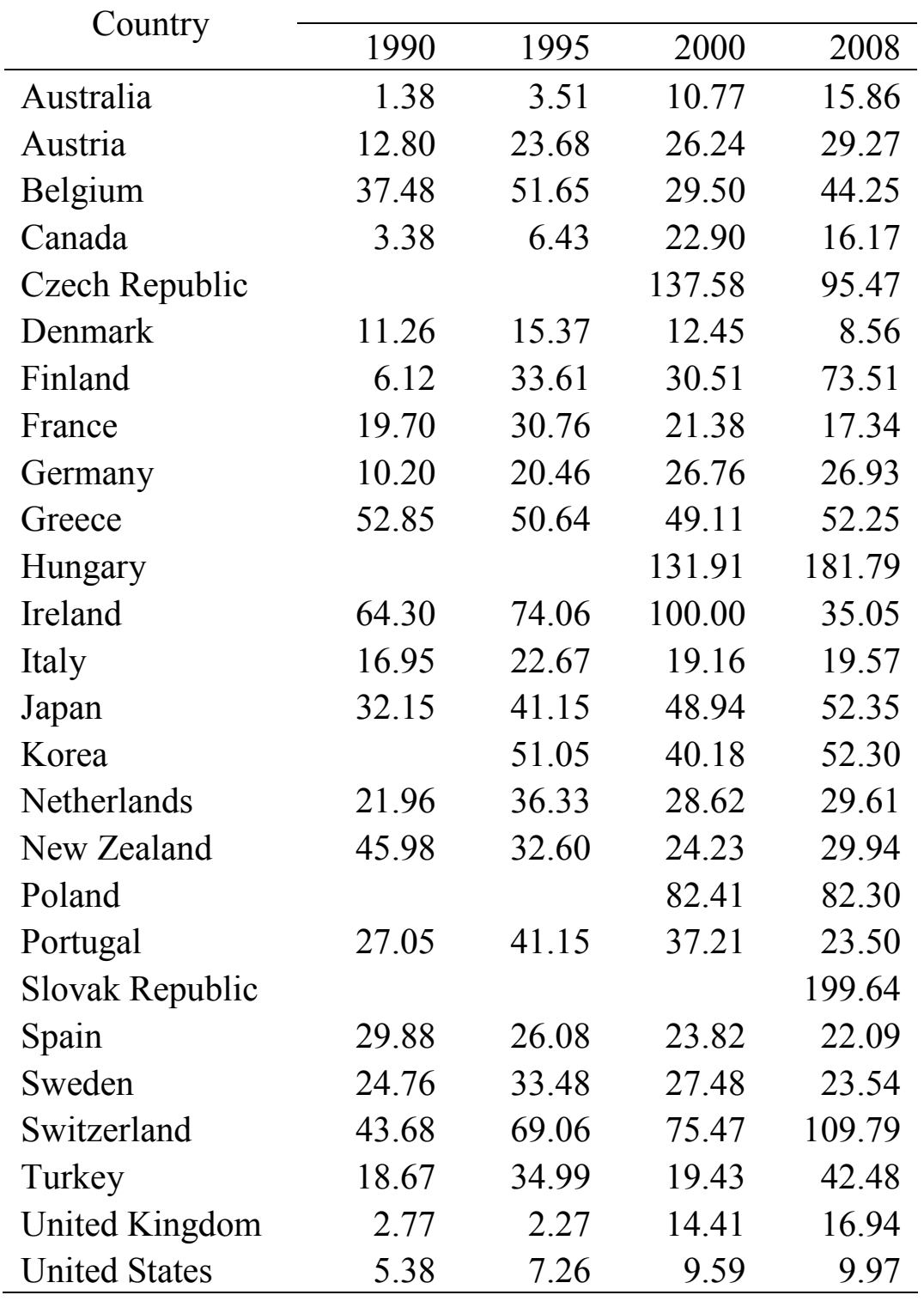


Table 5

Diversification Index (CSI) for Oil, Adjusted for Political Risk, Size and Distance

\begin{tabular}{|c|c|c|c|c|}
\hline Country & 1990 & 1995 & 2000 & 2008 \\
\hline Australia & 0.53 & 1.04 & 4.22 & 4.36 \\
\hline Austria & 6.70 & 9.81 & 11.02 & 9.04 \\
\hline Belgium & 20.00 & 13.22 & 7.75 & 11.02 \\
\hline Canada & 0.87 & 1.37 & 4.09 & 3.71 \\
\hline Czech Republic & & & 55.98 & 23.29 \\
\hline Denmark & 4.74 & 3.31 & 1.44 & 0.77 \\
\hline Finland & 1.15 & 6.09 & 9.26 & 17.65 \\
\hline France & 9.37 & 9.30 & 6.15 & 4.63 \\
\hline Germany & 4.47 & 7.13 & 10.49 & 7.26 \\
\hline Greece & 30.78 & 16.44 & 16.91 & 13.65 \\
\hline Hungary & & & 53.85 & 43.60 \\
\hline Ireland & 11.48 & 9.98 & 11.45 & 3.99 \\
\hline Italy & 9.89 & 8.39 & 7.76 & 5.58 \\
\hline Japan & 18.15 & 14.85 & 16.44 & 14.17 \\
\hline Korea & & 15.32 & 12.60 & 12.47 \\
\hline Netherlands & 11.43 & 9.66 & 7.40 & 7.33 \\
\hline New Zealand & 17.82 & 8.60 & 5.99 & 5.92 \\
\hline Poland & & & 34.16 & 20.20 \\
\hline Portugal & 13.41 & 14.64 & 13.68 & 6.98 \\
\hline Slovak Republic & & & & 47.78 \\
\hline Spain & 13.92 & 9.68 & 9.43 & 6.11 \\
\hline Sweden & 4.43 & 5.80 & 3.98 & 4.81 \\
\hline Switzerland & 18.62 & 26.73 & 29.51 & 21.13 \\
\hline Turkey & 11.33 & 10.70 & 7.07 & 11.82 \\
\hline United Kingdom & 0.69 & 0.37 & 1.95 & 2.16 \\
\hline United States & 6.08 & 5.94 & 8.67 & 9.85 \\
\hline
\end{tabular}


Table 6

Diversification index (CSI) for natural gas

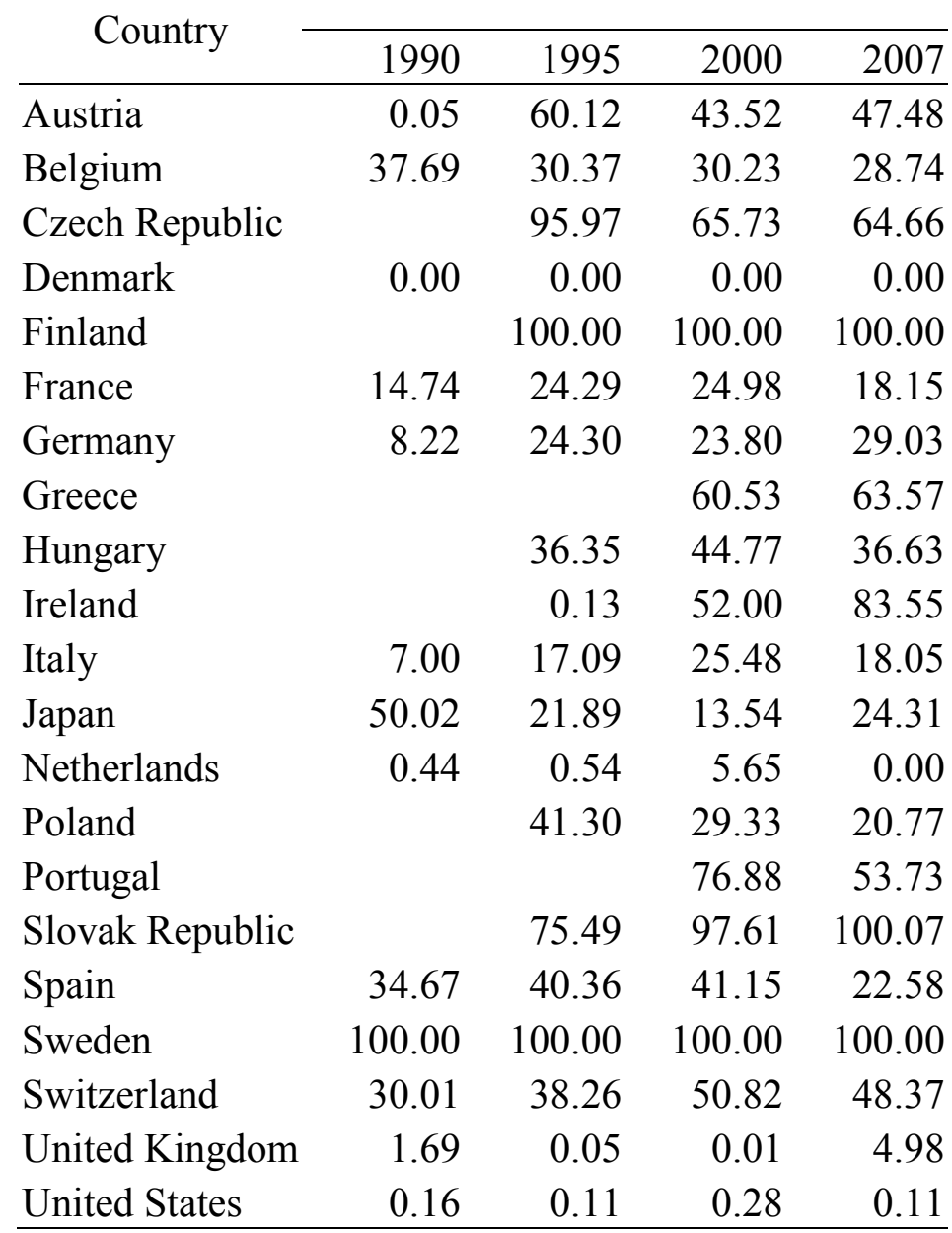


Table 7

Diversification Index (CSI) for Natural Gas, Adjusted for Political Risk

\begin{tabular}{lrrrr}
\multicolumn{1}{c}{ Country } & & & & \\
\cline { 2 - 5 } & 1990 & 1995 & 2000 & 2007 \\
\hline Austria & 0.01 & 23.55 & 17.24 & 9.97 \\
Belgium & 10.35 & 7.96 & 6.11 & 3.63 \\
Czech Republic & & 37.71 & 25.23 & 13.58 \\
Denmark & 0.00 & 0.00 & 0.00 & 0.00 \\
Finland & & 39.29 & 40.43 & 21.89 \\
France & 4.88 & 8.05 & 7.23 & 2.50 \\
Germany & 1.09 & 7.15 & 7.14 & 4.87 \\
Greece & & & 24.70 & 13.92 \\
Hungary & & 14.28 & 17.99 & 8.01 \\
Ireland & & 0.03 & 8.13 & 16.23 \\
Italy & 2.57 & 7.34 & 10.66 & 3.80 \\
Japan & 30.69 & 16.17 & 10.25 & 18.63 \\
Netherlands & 0.06 & 0.07 & 0.78 & 0.00 \\
Poland & & 16.23 & 11.83 & 4.53 \\
Portugal & & & 33.81 & 17.09 \\
Slovak Republic & & 29.66 & 39.46 & 21.91 \\
Spain & 15.40 & 17.59 & 17.42 & 5.69 \\
Sweden & 18.25 & 13.42 & 14.05 & 13.64 \\
Switzerland & 3.93 & 6.26 & 8.19 & 7.50 \\
United Kingdom & 0.23 & 0.01 & 0.00 & 0.44 \\
United States & 0.13 & 0.08 & 0.23 & 0.08 \\
\hline
\end{tabular}


Table 8

Diversification Index (CSI) for Natural Gas, Adjusted for Country Size

\begin{tabular}{lrrrr}
\multicolumn{1}{c}{ Country } & 1990 & 1995 & 2000 & 2007 \\
\cline { 2 - 5 } Austria & 0.05 & 61.34 & 44.21 & 48.08 \\
Belgium & 39.42 & 31.40 & 31.21 & 29.53 \\
Czech Republic & & 97.96 & 66.92 & 65.51 \\
Denmark & 0.00 & 0.00 & 0.00 & 0.00 \\
Finland & & 100.89 & 100.82 & 100.68 \\
France & 17.01 & 26.65 & 27.21 & 19.47 \\
Germany & 11.13 & 30.01 & 28.27 & 33.38 \\
Greece & & & 60.77 & 63.96 \\
Hungary & & 37.41 & 45.82 & 37.35 \\
Ireland & & 0.13 & 52.43 & 84.20 \\
Italy & 8.68 & 19.66 & 29.27 & 20.49 \\
Japan & 51.39 & 22.13 & 13.67 & 24.63 \\
Netherlands & 0.52 & 0.60 & 6.14 & 0.00 \\
Poland & & 42.49 & 30.04 & 21.24 \\
Portugal & & & 77.26 & 54.10 \\
Slovak Republic & & 76.74 & 98.97 & 101.00 \\
Spain & 35.63 & 41.35 & 42.68 & 23.93 \\
Sweden & 100.32 & 100.24 & 100.19 & 100.17 \\
Switzerland & 30.28 & 38.53 & 51.12 & 48.60 \\
United Kingdom & 2.19 & 0.07 & 0.01 & 5.79 \\
United States & 0.25 & 0.15 & 0.35 & 0.13 \\
\hline
\end{tabular}


Table 9

Diversification Index (CSI) for Natural Gas, Adjusted for Distance

\begin{tabular}{lcccc}
\multicolumn{1}{c}{ Country } & 1990 & 1995 & 2000 & 2007 \\
\cline { 2 - 5 } Austria & 0.05 & 119.95 & 85.76 & 91.91 \\
Belgium & 55.41 & 42.14 & 38.01 & 32.17 \\
Czech Republic & & 191.93 & 126.85 & 125.11 \\
Denmark & 0.00 & 0.00 & 0.00 & 0.00 \\
Finland & & 100.00 & 100.00 & 100.00 \\
France & 14.74 & 36.54 & 33.33 & 20.98 \\
Germany & 8.22 & 39.12 & 38.92 & 45.25 \\
Greece & & & 121.05 & 127.15 \\
Hungary & & 72.71 & 89.06 & 73.04 \\
Ireland & & 0.13 & 52.00 & 83.55 \\
Italy & 7.00 & 23.51 & 34.42 & 25.61 \\
Japan & 150.05 & 65.66 & 40.63 & 72.94 \\
Netherlands & 0.44 & 0.54 & 5.65 & 0.00 \\
Poland & & 41.30 & 29.33 & 20.77 \\
Portugal & & & 78.10 & 96.17 \\
Slovak Republic & & 150.99 & 195.21 & 200.14 \\
Spain & 38.00 & 45.51 & 45.07 & 33.38 \\
Sweden & 100.00 & 100.00 & 100.00 & 100.00 \\
Switzerland & 30.01 & 39.73 & 50.82 & 48.37 \\
United Kingdom & 1.69 & 0.05 & 0.01 & 4.99 \\
United States & 0.18 & 0.18 & 0.34 & 0.18 \\
\hline
\end{tabular}


Table 10

Diversification Index (CSI) for Natural Gas, Adjusted for Political Risk, Size and Distance

\begin{tabular}{lrrrr}
\multicolumn{1}{c}{ Country } & 1990 & 1995 & 2000 & 2007 \\
\cline { 2 - 5 } Austria & 0.01 & 48.21 & 35.09 & 20.26 \\
Belgium & 18.74 & 13.90 & 9.98 & 4.62 \\
Czech Republic & & 77.32 & 51.24 & 27.60 \\
Denmark & 0.00 & 0.00 & 0.00 & 0.00 \\
Finland & & 39.72 & 40.90 & 22.22 \\
France & 5.50 & 14.40 & 11.99 & 3.80 \\
Germany & 1.41 & 16.76 & 16.94 & 11.48 \\
Greece & & & 49.69 & 28.22 \\
Hungary & & 29.58 & 37.09 & 16.69 \\
Ireland & & 0.03 & 8.23 & 16.51 \\
Italy & 3.07 & 11.69 & 17.41 & 7.14 \\
Japan & 94.17 & 49.16 & 31.14 & 57.51 \\
Netherlands & 0.07 & 0.08 & 0.88 & 0.00 \\
Poland & & 16.79 & 12.24 & 4.76 \\
Portugal & & & 34.54 & 32.19 \\
Slovak Republic & & 60.52 & 80.49 & 44.72 \\
Spain & 17.57 & 19.34 & 19.38 & 9.96 \\
Sweden & 18.30 & 13.46 & 14.09 & 13.69 \\
Switzerland & 3.95 & 6.89 & 8.26 & 7.58 \\
United Kingdom & 0.29 & 0.01 & 0.00 & 0.61 \\
United States & 0.21 & 0.17 & 0.37 & 0.21 \\
\hline
\end{tabular}


Table 11

Energy Diversification Based on CSI Values in 2007-08

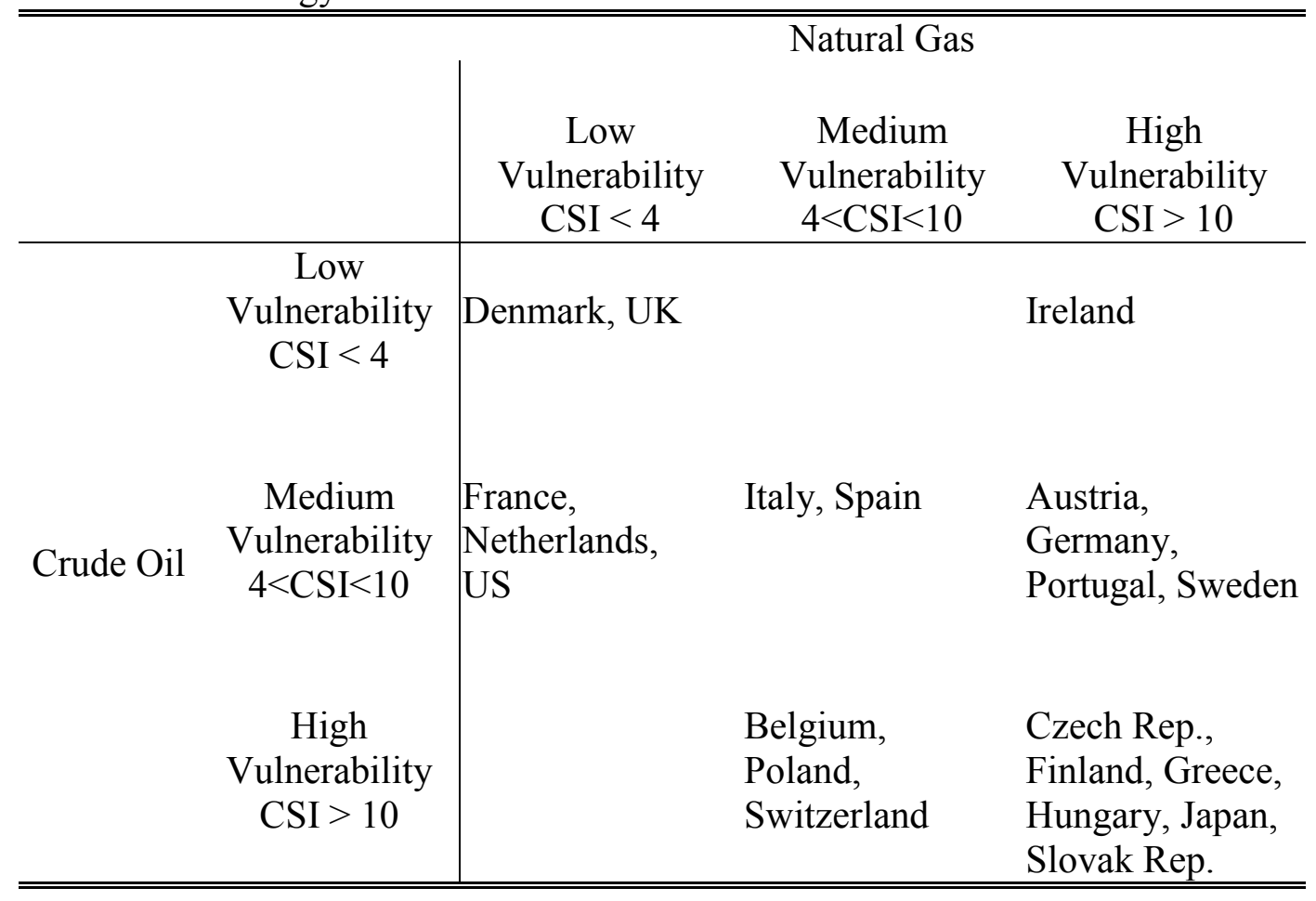


Table 12

Share-weighted Diversification Indices

(based on 2008 index for oil and 2007 index for natural gas)

\begin{tabular}{|c|c|c|c|c|}
\hline Country & $\begin{array}{l}\text { CSI (weighted) (oil } \\
\text { and gas shares } \\
\text { normalized to sum } \\
\text { to } 1 \text { ) }\end{array}$ & $\begin{array}{c}\text { CSI (weighted) } \\
\text { weighted by oil and } \\
\text { gas shares }\end{array}$ & Share of oil & Share of gas \\
\hline Austria & 14.13 & 6.82 & 26.37 & 21.87 \\
\hline Belgium & 9.08 & 6.15 & 47.18 & 20.54 \\
\hline Czech Republic & 25.27 & 8.99 & 19.23 & 16.34 \\
\hline Denmark & 0.52 & 0.36 & 46.78 & 22.44 \\
\hline Finland & 18.76 & 10.42 & 42.02 & 13.54 \\
\hline France & 4.37 & 2.08 & 32.41 & 15.10 \\
\hline Germany & 9.01 & 5.37 & 34.75 & 24.78 \\
\hline Greece & 15.91 & 9.94 & 52.83 & 9.67 \\
\hline Hungary & 27.33 & 19.52 & 28.25 & 43.18 \\
\hline Ireland & 10.67 & 5.58 & 24.42 & 27.88 \\
\hline Italy & 6.27 & 5.50 & 48.74 & 38.96 \\
\hline Japan & 27.10 & 14.31 & 37.06 & 15.75 \\
\hline Netherlands & 4.34 & 3.99 & 54.44 & 37.42 \\
\hline Poland & 14.43 & 5.03 & 21.82 & 13.02 \\
\hline Portugal & 12.82 & 8.83 & 52.94 & 15.95 \\
\hline Slovak Republic & 46.33 & 28.27 & 32.09 & 28.94 \\
\hline Spain & 7.44 & 4.62 & 40.76 & 21.36 \\
\hline Sweden & 5.17 & 2.43 & 45.01 & 1.90 \\
\hline Switzerland & 16.36 & 4.34 & 17.18 & 9.33 \\
\hline United Kingdom & 1.38 & 1.05 & 37.79 & 38.17 \\
\hline United States & 5.69 & 3.33 & 33.32 & 25.23 \\
\hline
\end{tabular}




\section{References}

Blyth,W., Lefevre, N., 2004. Energy Security and Climate Change. International Energy Agency Information Paper.

BP, 2007. BP Statistical Review of World Energy June 2007, http://www.bp.com/conversionfactors.jsp

Bryce, Robert, The Dangerous Delusions of “Energy Independence”. New York, NY: Public Affairs, 2008.

Council on Foreign Relations, 2006, National Security Consequences of U.S. Oil Dependency, Independent Task Force Report No.58.

European Commission, 2000.Towards a European Strategy for the Security of Energy Supply. Green Paper, COM769.

European Commission, 2006.A European strategy for sustainable, competitive and secure energy. Green Paper, COM105.

Gupta, Eshita, (2008), Oil vulnerability index of oil-importing countries. Energy Policy 36 (3), 1195-1211.

Hakes, Jay, A Declaration of Energy Independence: How Freedom from Foreign Oil Can Improve National Security, Our Economy, and the Environment. Hoboken, NJ: John Wiley \& Sons, Inc., 2008

Kilic, A.M., 2006, Turkey's natural gas necessity, consumption and future perspectives, Energy Policy 34, 1928-34

LaCasse, Chantale and Andre Plourde, 1995, On the Renewal of Concern for the Security of Oil Supply, Energy Journal, vol. 16, no. 2, 1-23.

Le Coq, Chloe and Elena Paltseva, 2008. Common Energy Policy in the EU: The Moral Hazard of the Security of External Supply. SIEPS Report 2008:1.

Le Coq, Chloe and Elena Paltseva, 2009. Measuring the security of external energy supply in the European Union, Energy Policy 37 (2009) 4474-4481

Loschel, Andreas, Ulf Moslener and Dirk Rubbelke, 2010a. Energy Security-concepts and indicators, Energy Policy 38 (2010) 1607-08.

Loschel, Andreas, Ulf Moslener and Dirk Rubbelke, 2010b. Indicators of Energy Security in Industrialized Countries, Energy Policy 38 (2010) 1665-71. 
Loungani, Prakash, 2009, The Elusive Quest for Energy Independence, International Finance, Volume 12, Issue 2, 291- 99.

Neumann, A., 2004. Security of Supply in Liberalised European Gas Markets. Diploma Thesis, European University Viadrina.

Neumann, A., 2007.How to measure security of supply? Mimeo, Dresden University of Technology.

OECD Economic Outlook No. 76, 2004.

PRS (Political Risk Services) Group, http://www.prsgroup.com/

Rosendahl, Knut Einar and Sagen, Eirik Lund (2009), The Global Natural Gas Market: Will Transport Cost Reductions Lead to Lower Prices? ', Energy Journal, Vol. 30, No.2, 17-39.

Sandalow, David, Freedom from Oil: How the Next President Can End the United States' Oil Addiction. New York, NY: The McGraw-Hill Companies.

Serletis, Apostolos, Govinda Timilsina and Olexandr Vasetsky, 2009. "On interfuel substitution: some international evidence," Policy Research Working Paper Series 5026, The World Bank.

Van der Linde, C., Amineh, M.P., Correlje A., de Jong, D., 2004. Study on Energy Supply Security and Geopolitics, CIEP Report, Clingendael International Energy Programme, The Hague.

Yergin, Daniel (2009), The Long Aftershock: Oil and Energy Security after the Price Collapse," Testimony to the Joint Economic Committee (JEC) of the U.S. Congress, May 20, 2009. 